\title{
Özofagusun fungal enfeksiyonları; tek merkez deneyimi
}

\author{
Fungal infections of the esophagus: Single center experience
}

Enver AKBAŞ

Istanbul Medipol Unniversitesi Tip Fakültesi, Gastroenteroloji Bölümü, Istanbul

\begin{abstract}
Giriş ve Amaç: Araştırmamızda hastanemizde çeşitli endikasyonlar ile üst gastrointestinal sistem endoskopisi yapılan hastalarda özofagus fungal enfeksiyonlarının sıklığını, başvuru semptomlarının dağılımını, buna zemin hazırlayan durumları değerlendirmeye çalıştık. Gereç ve Yöntem: 2015-2019 yilları arasinda hastanemize bassvuran ve üst gastrointestinal sistem endoskopisi yapılan 2862 hastadan endoskopik olarak özofagusta fungal enfeksiyon tespit edilen ve mikrobiyolojik olarak bu tanısı doğrulanan 33 hasta değerlendirmeye alındı. Bulgular: Toplam 2862 hastanin $33(\% 1,2)$ tanesinde özofagusta fungal enfeksiyon tespit edildi. Eşlik eden hastalık olarak en sık $\% 71$ ile reflü özofajit zemininde fungal enfeksiyon gelişmişti. Hiçbir hastada insan bağıșıllık yetmezliği virüsü pozitifliği tespit edilemedi. Hastaların $\% 27,3$ 'ünde immünsupresyona neden olan bir patoloji ya da ilaç kullanımı mevcut iken \% 72,7'sinde böyle bir neden tespit edilemedi. Hastaların basvuru şikayeti olguların \%21.2'sinde disfaji, \%6.l'inde hıçkırık, \%21.2'sinde reflü semptomlanı, \%6.1'inde ses kisıkllğı, \%6.1'inde kilo kaybı, \%15.2'sinde bulantı-kusma iken \%42.4 ile hastaların çoğunluğunda mide ağrısı gibi klasik bir dispeptik yakınma şeklindeydi. Sonuç: Dünyada Kandida özofajitinin en sık nedeni insan bağışıklık yetmezliği virüsü enfeksiyonu, maligniteler ve immünsüpresyon yaratan durumlardır. Bizim hastalarımızda Kandida enfeksiyonuna daha çok reflü özofajit eşlik etmekte iken sadece \%15 hastada enfeksiyon immünsüpresyon yaratan bir durumda gelişmişti. Bulgularımız insan bağışıklık yetmezliği virüsü negatif hasta profilindeki dünya literatür verileri ile uyumu bulundu.
\end{abstract}

Anahtar kelimeler: Özofagusun fungal enfeksiyonları, Kandida özofajiti, kandidiyazis

\section{GİRISS}

Enfeksiyöz özofajite en sık yol açan etken Kandida'dır (1). Kandida'ya bağlı özofajit genellikle altta yatan özofageal ya da sistemik bir hastalığa bağlı olarak gelişir. Kandida enfeksiyonları orofarinks ve özofagus gibi lokal mukoz mebranları tutabilir veya fokal ya da sistemik olarak invaziv enfeksiyonlar da gelişebilir. Etken genellikle Candida albicans (C. albicans) olmasına rağmen Candida glabrata, Candida krusei ve Candida tropicalis gibi öteki türler de enfeksiyon etkeni olaral özofagustan izole edilebilir $(2,3)$. Özofageal kandidiyazis, edinsel immün yetmezlik sendromu (AIDS)'e bağlı bir hastalık olduğu için insan bağışıklık yetmezliği virüsü (HIV) ile enfekte hastalarda ve hematolojik maligniteli hastalarda sık görülür. Neden olan organizma, diğer türler nadir olup neredeyse her zaman C. albicans'tır $(4,5)$. Bununla birlikte sistemik immün
Background and Aims: Our study investigated the prevalence of esophageal fungal infections, distribution of presenting symptoms, and predisposing conditions in the patients undergoing upper gastrointestinal endoscopy for various reasons at our hospital. Materials and Methods: Overall, 2862 patients presented to our hospital and underwent upper gastrointestinal endoscopy between 2015 and 2019. Thirty-three of these patients who were endoscopically determined and microbiologically confirmed to have esophageal fungal infections were included. Results: Esophageal fungal infection was found in 33 (1.2\%) of 2862 patients. Fungal infections developed most frequently as a comorbid disease in the setting of reflux esophagitis, with a rate of $71 \%$. No patient was found to have human immunodeficiency virus seropositivity. Even though $27.3 \%$ of patients had pathological or drug-induced immune suppression, no such findings were noted in $72.7 \%$ of patients. The presenting complaint was dysphagia in $21.2 \%$ of patients, hiccough in $6.1 \%$, reflux symptoms in $21.2 \%$, hoarseness in $6.1 \%$, weight loss in $6.1 \%$, and nausea or vomiting in $15.2 \%$; however, in most patients, the presenting complaint was a classical dyspeptic complaint, such as stomach ache (42.4\%). Conclusion: The most common causes of Candida esophagitis worldwide are human immunodeficiency virus infection, malignancies, and conditions that result in immune suppression. Even though Candida esophagitis was more commonly associated with reflux esophagitis in our patients, fungal infection was also observed in 15\% of patients along with diseases that rendered them immunocompromized. Our results were concordant with the literature data regarding the clinical profile of patients who are human immunodeficiency virus negative.

Key words: Fungal infections of the esophagus, Candida esophagitis, candidiasis

yetmezliği olmayan hastalarda, antibiyotik veya steroid türü ilaç kullanımı, alkol tüketimi, diabetes mellitus ve özofagusta staz oluşturan akalazya ve skleroderma gibi hastalıklarda özofageal kandidiyazis gelişebilir (6-10). Bu enfeksiyona yol açan nedenlerden biri de reflü özofajitidir (1). Özofagus kandidiyazisinin belirgin özelliği, hastaların genellikle retrosternal alanda tanımladığı odinofaji veya yutma esnasında ağrıdır. Bizim hastalarımızda yutma güçlüğüne ilaveten, hıçkırık, ses kısıklığı, kilo kaybı, eşlik eden reflüye ait semptomlar da görülen semptomlar arasinda idi.

\section{GEREÇ ve YÖNTEM}

Çalışma 2015-2019 yılları arasında Medipol Üniversitesi Eğitim ve Araştırma Hastanesi Gastroenteroloji Kliniği'nde özo- 

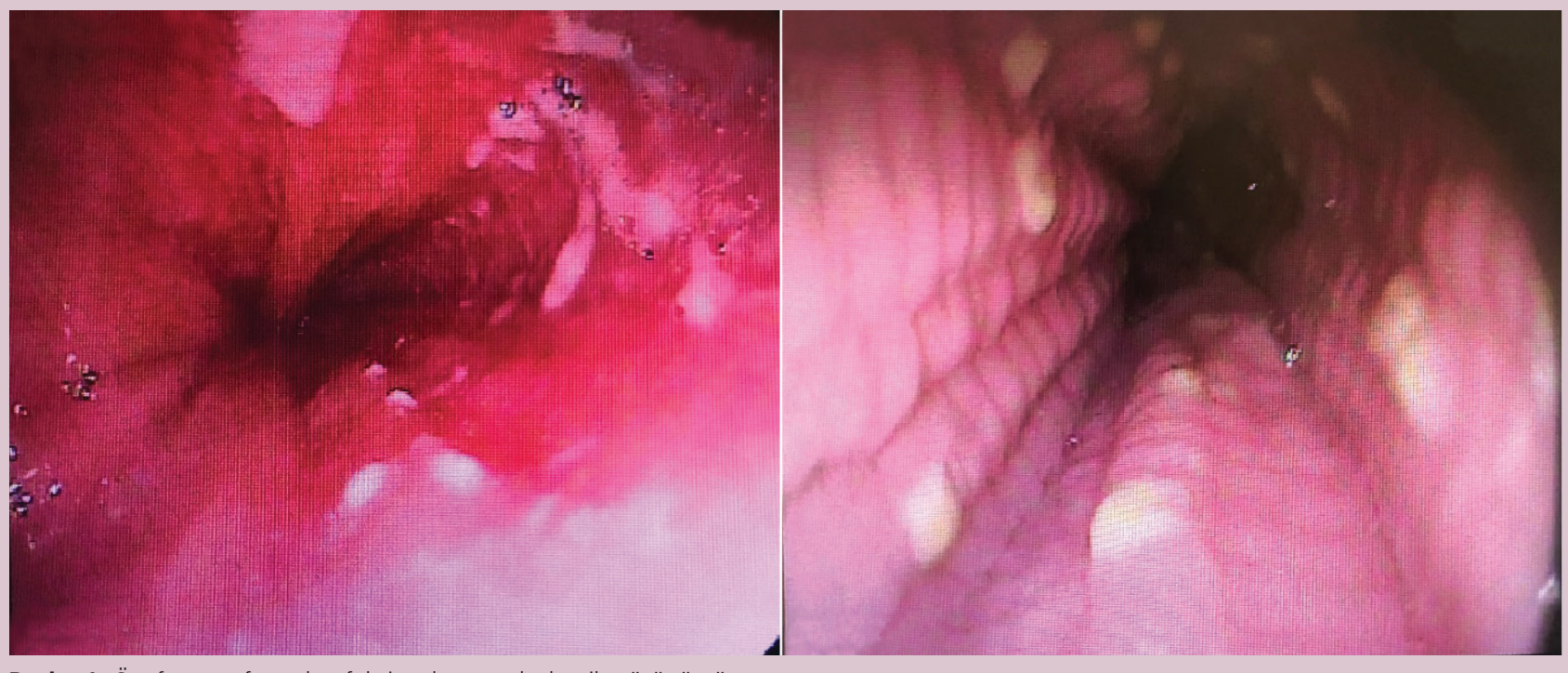

Resim 1. Özofagusta fungal enfeksiyonların endoskopik görünümü

fagogastroduodenoskopi yapılan \%46.5'i (n=1313) erkek, \%53.5’i ( $\mathrm{n=1513)}$ kadın olmak üzere toplam 2826 olgunun retrospektif olarak değerlendirilmesi ile yapılmıştır. Hastalarda özofageal fungal enfeksiyon tanısı endoskopi esnasında özofagus mukozasının değişik kısımlarında görülen beyaz mukozal plaklardan fırça ile mukozal sürüntü örnekleri alınması ve bu sürüntü örneklerinde mikrobiyolojik inceleme yapılması ile konuldu. Direkt gram boyamasinda maya ve psödohif yapılarının görülmesi ile tanı kesinleşmiş oldu. Resim l'de özofagusta fungal enfeksiyon tespit edilen hastalarımızın endoskopik görüntüsü yer almaktadır.

\section{İstatistiksel İncelemeler}

İstatistiksel analizler için NCSS (Number Cruncher Statistical System) 2007 (Kaysville, Utah, USA) programı kullanıld. Çalışma verileri değerlendirilirken tanımlayıcı istatistiksel metodlar (ortalama, standart sapma, medyan, frekans, oran, minimum, maksimum) kullanıldı.

\section{BULGULAR}

Çalışmada gastroskopi yapılan toplam 2826 vakadan 1313'ü (\%46.5) erkek, 1513'ü (\%53.5) kadın idi. Bu hastalardan sadece 33 (\%1.2) tanesinde özofagusta fungal enfeksiyon tespit edilmiştir. Özofagus fungal enfeksiyonu saptanan hastaların \%54.5'i (n=18) erkek, \%45.5'i (n=15) kadındır. Tablo l'de gastroskopi yapılan tüm hastalarda özofagusta fungal enfeksiyonların dağılımı ifade edilmektedir.

Özofagus fungal enfeksiyonu saptanan hastaların yaşları 20 ile 75 arasında değişmekte olup, ortalama $47.27 \pm 15.56$ ylldır. Cinsiyete göre bakıldığında ise özofagus fungal enfeksiyonu saptanan erkek olguların yaşları 20 ile 75 arasında

Tablo 1. Gastroskopi yapılan hastalarda fungal enfeksiyonların dağılımı

$\begin{array}{lcr}\text { Gastroskopi yapılan toplam hasta }(\mathbf{n}=\mathbf{2 8 2 6}) & & \\ \text { Cinsiyet } & \text { Erkek } & 1313(46.5) \\ & \text { Kadın } & 1513(53.5) \\ \text { Özofagus fungal enfeksiyonu } & \text { Yok } & 2793(98.8) \\ & \text { Var } & 33(1.2) \\ \text { Özofagus fungal enfeksiyonu saptanan hastalar (n=33) } & & 18(54.5) \\ \text { Cinsiyet } & \text { Erkek } & 15(45.5) \\ & \text { Kadın } & 20-75(47) \\ \text { Yaş (yıl) } & \text { Min-Mak (Medyan) } & 47.27 \pm 15.56\end{array}$


değişmekte olup, ortalama $46.83 \pm 16.15$ yıl; kadın olguların ise 23 ile 74 arasında değişmekte olup, ortalama 47.80 \pm 15.35 yıldır. Hastaların büyük bir kısmında özofagustaki fungal enfeksiyona eşlik eden veya zemin hazırlayan başka bir patolojik olay da mevcuttu.

Özofagusta fungal enfeksiyon saptanan 33 olgunun \%78.8'inde ( $\mathrm{n}=26)$ eşlik eden başka hastalıklar görülmektedir; erkeklerin \%88.9'unda ( $\mathrm{n}=16)$, kadınların ise \%66.7'sinde $(n=10)$ eşlik eden başka hastalıklar mevcuttur. Özofagusta fungal enfeksiyon saptanan hastalarda eşlik eden hastalıkların dağılımı Tablo 2'de, grafiksel gösterimi ise Figür l'de ifade edilmektedir.

Tüm olguların \%69.7'sinde (n=23) reflü özofajit, \% 15.2'sinde $(\mathrm{n}=5)$ immünsüpresyon yapan bir durum, \%12.1'inde (n=4) gastrik ülser, \%3.0'ünde (n=1) duodenal ülser ve \%9.1'inde $(n=3)$ çeşitli kanserler görülmektedir.

Erkek olguların \%83.3'ünde ( $n=15)$ reflü özofajit, \%16.7'sinde $(n=3)$ immünsüpresyon yapan bir durum, \%22.2'sinde $(n=4)$ gastrik ülser, \%5.6'sinda $(n=1)$ duodenal ülser ve \%5.6'sında ( $\mathrm{n}=1)$ kanserler görülmektedir. Kadın olguların \%53.3'ünde ( $\mathrm{n}=8)$ reflü özofajit, \%13.3'ünde (n=2) immün- süpresyon yapan bir durum ve \%13.3'ünde (n=2) kanserler görülmektedir.

Özofagusta fungal enfeksiyon saptanan olguların \%93.9'unda hekime bir ya da bir kaç başvuru şikayeti görülmektedir; erkeklerin \%88.9'unda ( $\mathrm{n}=16)$, kadınların ise \%100'ünde $(\mathrm{n}=15)$ hekime bir başvuru şikayeti mevcuttur. Hastaların hekime başvuru şikayetleri de değişkenlikler göstermektedir. Hastaların hekime başvuru şikayetlerinin dağılımı Tablo 3'e, grafiksel gösterimi ise Figür 2'de yer almaktadır.

Tüm olguların \%21.2'sinde ( $\mathrm{n}=7)$ disfaji, \%6.1'inde (n=2) hıçkırık, \%21.2'sinde (n=7) reflü semptomları, \%6.1'inde ( $n=2)$ ses kısıklığı, \%6.1'inde (n=2) kilo kaybı, \%15.2'sinde (n=5) bulantı-kusma ve \%42.4'ünde (n=14) mide ağrısı görülmektedir.

Erkek olguların \%16.7'sinde ( $\mathrm{n}=3)$ disfaji, \%11.1'inde ( $\mathrm{n}=2)$ hıçkırık, \%22.2'sinde (n=4) reflü semptomları, \%5.6'sında $(\mathrm{n}=1)$ ses kisıklığı, \%5.6'sında ( $\mathrm{n}=1)$ kilo kaybı, \%16.7'inde $(\mathrm{n}=3)$ bulantı-kusma ve \%33.3'ünde $(\mathrm{n}=6)$ mide ağrısı görülmektedir. Kadın olguların \%26.7'sinde (n=4) disfaji, \%20 .0'sinde (n=3) reflü semptomları, \%6.7'sinde $(\mathrm{n}=1)$ ses kısıklığı, \%6.7'sinde ( $\mathrm{n}=1)$ kilo kaybı, \%13.3'ünde (n=2) bulantı-kusma ve \%53.3'ünde (n=8) mide ağrısı görülmektedir.

\section{Tablo 2. Özofagusta fungal enfeksiyon saptananlarda eşlik eden hastalıkların dağılımı}

\begin{tabular}{|c|c|c|c|c|}
\hline & & $\begin{array}{c}\text { Özofagus fungal } \\
\text { enfeksiyonu } \\
\text { saptanan toplam }(n=33)\end{array}$ & $\begin{array}{c}\text { Erkek } \\
(n=18)\end{array}$ & $\begin{array}{l}\text { Kadın } \\
(n=15)\end{array}$ \\
\hline & & n (\%) & n (\%) & n (\%) \\
\hline \multirow[t]{2}{*}{ Eşlik eden hastalık } & Yok & $7(21.2)$ & $2(11.1)$ & $5(33.3)$ \\
\hline & Var & $26(78.8)$ & $16(88.9)$ & $10(66.7)$ \\
\hline \multirow[t]{5}{*}{ Eşlik eden hastalıklar } & Reflü özofajit & $23(69.7)$ & $15(83.3)$ & $8(53.3)$ \\
\hline & Immünsüpresyon & $5(15.2)$ & $3(16.7)$ & $2(13.3)$ \\
\hline & Gastrik ülser & $4(12.1)$ & $4(22.2)$ & $0(0)$ \\
\hline & Duodenal ülser & $1(3.0)$ & $1(5.6)$ & $0(0)$ \\
\hline & Kanserler & $3(9.1)$ & $1(5.6)$ & $2(13.3)$ \\
\hline
\end{tabular}

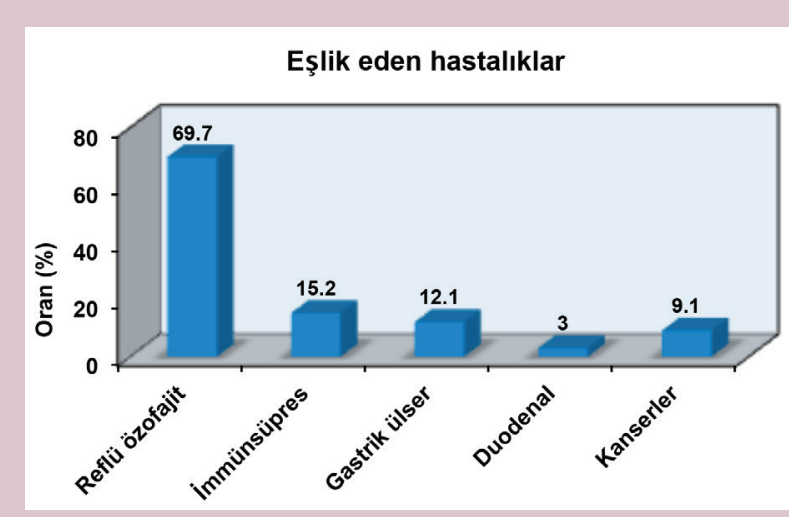

Figür 1. Özofagusta fungal enfeksiyon saptanan hastalarda eşlik eden hastalıkların dağıımı

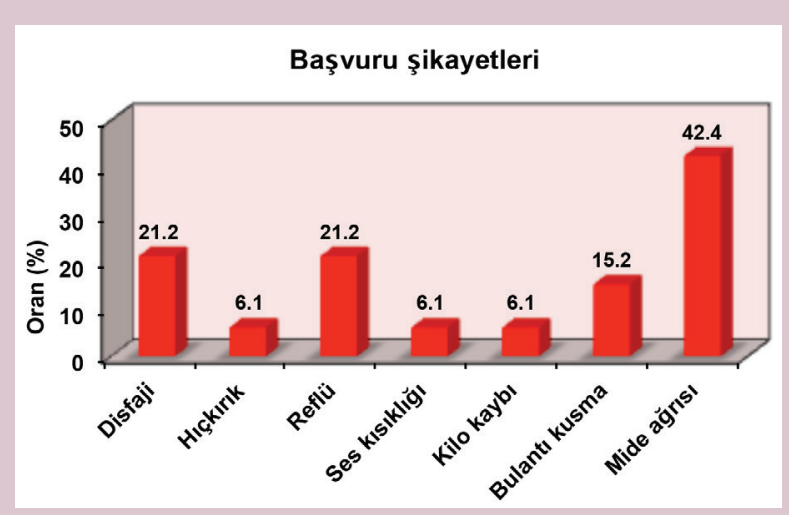

Figür 2. Özofagusta fungal enfeksiyon saptanan hastalarda cinsiyetlere göre başvuru şikayetlerinin dağıımı 


\begin{tabular}{|c|c|c|c|c|}
\hline & & $\begin{array}{c}\text { Özofagus fungal } \\
\text { enfeksiyonu saptanan } \\
\text { toplam }(\mathbf{n}=33)\end{array}$ & $\begin{array}{c}\text { Erkek } \\
(n=18)\end{array}$ & $\begin{array}{l}\text { Kadın } \\
(n=15)\end{array}$ \\
\hline & & n (\%) & n (\%) & n (\%) \\
\hline \multirow[t]{2}{*}{ Başvuru şikayeti } & Yok & $2(6.1)$ & $2(11.1)$ & $0(0)$ \\
\hline & Var & $31(93.9)$ & $16(88.9)$ & $15(100)$ \\
\hline \multirow[t]{7}{*}{ Başvuru şikayetleri } & Disfaji & $7(21.2)$ & $3(16.7)$ & $4(26.7)$ \\
\hline & Hıçkırık & $2(6.1)$ & $2(11.1)$ & $0(0)$ \\
\hline & Reflü semptomları & $7(21.2)$ & $4(22.2)$ & $3(20)$ \\
\hline & Ses kısıklığı & $2(6.1)$ & $1(5.6)$ & $1(6.7)$ \\
\hline & Kilo kaybı & $2(6.1)$ & $1(5.6)$ & $1(6.7)$ \\
\hline & Bulantı kusma & $5(15.2)$ & $3(16.7)$ & $2(13.3)$ \\
\hline & Mide ağrısı & $14(42.4)$ & $6(33.3)$ & $8(53.3)$ \\
\hline
\end{tabular}

\begin{tabular}{|c|c|c|c|c|}
\hline & & $\begin{array}{l}\text { Özofagus fungal } \\
\text { enfeksiyonu saptanan } \\
\text { toplam }(n=33)\end{array}$ & $\begin{array}{l}\text { Erkek } \\
(n=18)\end{array}$ & $\begin{array}{l}\text { Kadın } \\
(n=15)\end{array}$ \\
\hline & & n (\%) & n (\%) & n (\%) \\
\hline İmmünsüpresyon & $\begin{array}{l}\text { Yok } \\
\text { Var }\end{array}$ & $\begin{array}{c}24(72.7) \\
9(27.3)\end{array}$ & $\begin{array}{c}13(72.2) \\
5(27.8)\end{array}$ & $\begin{array}{c}11(73.3) \\
4(26.7)\end{array}$ \\
\hline
\end{tabular}

Bilindiği üzere özofagusta fungal enfeksiyonlara zemin hazırlayan durumların başında maligniteler, kemoterapötik ilaçların kullanımı ve AIDS gibi immünsüpresyon oluşturan enfeksiyonlar başta gelen nedenler arasındadır. Bizim hastalarımızın hiç birisinde HIV pozitifliği mevcut değildi. Hastalarımızın sadece üçte birinden az bir kısmında immün sistemi baskılayabilecek bir patoloji mevcut iken geri kalanında böyle bir neden tespit edilemedi. Immünsüpresyon yapan durumlar başlığı altında, maligniteler, immünsüpressif ve kemoteropötik ilaçlar ile kortikosteroidlerin kullanımı olarak değerlendirilmiştir. Özofagusta fungal enfeksiyon saptan hastalarda immünsüpresyona yol açan durumların varlığı Tablo 4'te, grafiksel gösterimi ise Figür 3'te gösterilmektedir.

Özofagus fungal enfeksiyonu saptanan olguların \%27.3'ünde (n=9) immünsüpresyon yapan bir durum görülmektedir; erkeklerin \%27.8'inde ( $\mathrm{n}=5)$, kadınların ise \%26.7'sinde $(\mathrm{n}=4)$ immünsüpresyona neden olabilecek bir durumu söz konusudur.

Özofagus fungal enfeksiyonu saptanan hastaların \%90.9'unda (n=33) 1 ay süreyle haftada bir $200 \mathrm{mg}$ oral flukonazol ve 1 haftalık oral nistatin ile antifungal tedaviye yanıt görülmüştür, sadece \%9.1'inde $(n=3)$ ise kontrol endoskopide hastada fungal enfeksiyonun devam ettiği saptanmıştır. Aynı tedavinin tekrarı ile bu vakalarda da enfeksiyon eradike edilebilmiştir.

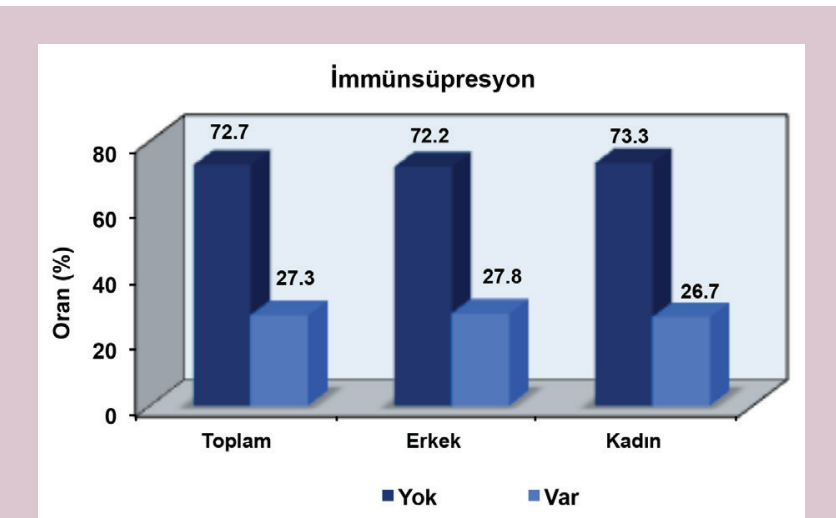

Figür 3. Özofagusta fungal enfeksiyon saptanan hastalarda immünsüpresyon oranlarının dağılımı

\section{TARTIŞMA}

Enfeksiyöz özofajit hastalarının \%88'i C. albicans ile oluşur. Özofageal kandidiyazisli hastalar asemptomatik veya çok çeşitli semptomlara sahip olabilir. En sık görülen semptomlar disfaji, odinofaji ve retrosternal ağrıdır. Yemek borusunun Kandida enfeksiyonları fırsatçı enfeksiyonlar olarak kabul edilir ve en çok immün sistemi baskılanmış hastalarda görülürler. $(11,12)$. Yeni epidemiyolojik çalışmalar, kandidiyazis sıklığının 100.000'de 1.2 ile 25 arasında değiştiğini göstermiştir $(13,14)$. HIV negatif hastalarda özofageal fungal 
enfeksiyonların değerlendirildiği Mayo Klinik çalışmasında 3 yıllık izlemde yaklaşık 42.847 hastalık endoskopi serisinde 218 hastada fungal özofajit tesbit edilmişti ve prevalans \%0.5 idi. Bu hastalarm 111 tanesinde bir veya daha fazla altta yatan disfaji nedeni vardı. Bunlardan dismotilite 15, özofagus kanseri 17, gastroözofageal reflü hastalığ1 69 , eozinofilik özofajit 12, özofagus liken planusu 4, geçirilmiş özofagus ameliyat1 23 vakada tespit edilmiş idi (15). Yutaka ve ark. 80.219 hastalık endoskopi serisinde yaptıkları çalışmada Kandida özofajiti prevalansı tüm hastalarda \% 1.7, HIV ile enfekte hastalarda \%9.8 ve HIV ile enfekte olmayan hastalarda \%1.6 idi. Enfeksiyon için risk analizinde, ileri yaş, HIV enfeksiyonu ve kortikosteroid kullanımı ile Kandida enfeksiyonu arasında anlamlı bir ilişki olduğunu ortaya koymuştu. Sigara kullanı$\mathrm{m}$ ve asetaminofen kullanımı ile ilişkisi ise sınırda anlamlılık gösteriyordu. Alkol tüketimi, hepatit B veya $C$ virüsü, sifiliz, diabetes mellitus, kardiyovasküler hastalık, serebrovasküler hastalık, kronik böbrek hastalığı, karaciğer sirozu, antikanser veya proton pompası inhibitörü (PPI) kullanımı ile anlamlı bir ilişki bulunamamıştı (10). HIV pozitif ve HIV negatif olmak üzere iki gruba ayrlan ve toplam 6011 hastanin değerlendirildiği benzer bir çalışmada ise üst gastrointestinal endoskopide hastaların \%33.4'ünde organik bir hastalık tespit edilmişti. 430 HIV pozitif ve 5581 HIV negatif hastanın değerlendirmesinde Kandida özofajiti ve eroziv reflü özofajit sıklığı HIV ile enfekte hastalarda sirasıyla \%11.2 ve \%12.1 iken, HIV negatif hastalarda sirasiyla \%2.9 ve \%10.7 idi. Organik lezyonu olmayan HIV pozitif hastalarda açlık krampları, bulantı, erken doyma, geğirme, disfaji ve odinofaji, HIV negatif olanlara göre daha sik idi (16). Bu enfeksiyona yol açan nedenlerden birinin de reflü özofajit olduğu çalışmalarda gösterilmiştir (1). Bizim hastalarımızdan hiç birisinde HIV pozitifliği mevcut değildi. Çeşitli endikasyonlar ile üst gastrointestinal sistem (GIS) endoskopisi yapılan hastaların $\% 1.2$ 'sinde özofagusta fungal enfeksiyon tespit edilmişti. En sık eşik eden durum hastaların yaklaşık \%70'inde görülen reflü özofajit idi. Hastaların \%27.3'ünde immün sistemi baskılayan bir ek hastalık veya ilaç kullanımı mevcut idi. Inhale kortikosteroid kullanımı, diyabet, ileri yaş ve bazen de malignite fungal enfeksiyona zemin hazırlayan durum olarak görülmekteydi. Disfaji ve reflü semptomları \%21 vakada görülürken hıçkırık, ses kısıklığı ve kilo kaybı \%6 vakada hastaneye başvuru semptomu olarak görülmüştür. Çalışmamızın sonuçları, dünyada HIV negatif hastalarda görülen Kandida özofajit prevalansı, eşlik eden hastalık durumu ve semptomatolojisi ile benzer özellikler taşımakta idi. Sadece eşlik eden organik hastalık olarak reflü özofajitin sıklığı ve semptom olarak hıçkırık diğer araştırmalarda vurgulanan bir bulgu değildi.

\section{KAYNAKLAR}

1. Polis MA: Esophagitis. In: Mandell GL, Bennett JE, Dolin RD (Eds.) Principles and Practice of Infectious Diseases. New York, Churchill. Livingstone: 1995;962-5.

2. Sangeorzan JA, Bradley SF, He X, et al. Epidemiology of oral candidiasis in HIV-infected patients: colonization, infection, treatment, and emergence of fluconazole resistance. Am J Med 1994;97:339-46.

3. Barchiesi F, Morbiducci V, Ancarani F, Scalise G. Emergence of oropharyngeal candidiasis caused by non-albicans species of Candida in HIV-infected patients. Eur J Epidemiol 1993;9:455-6.

4. Bonacini M, Young T, Laine L. The causes of esophageal symptoms in human immunodeficiency virus infection. A prospective study of 110 patients. Arch Intern Med 1991;151:1567-72

5. Darouiche RO. Oropharyngeal and esophageal candidiasis in immunocompromised patients: treatment issues. Clin Infect Dis 1998;26:25972.

6. Chocarro Martinez A, Galindo Tobal F, Ruiz-Irastorza G, et al. Risk factors for esophageal candidiasis. Eur J Clin Microbiol Infect Dis 2000;19:96-100

7. Weerasuriya N, Snape J. A study of candida esophagitis in elderly patients attending a district general hospital in the UK. Dis Esophagus 2006;19:189-92.

8. Yakoob J, Jafri W, Abid S, et al. Candida esophagitis: risk factors in nonHIV population in Pakistan. World J Gastroenterol 2003;9:2328-31.

9. Choi JH, Lee CG, Lim YJ, Kang HW, Lim CY, Choi JS. Prevalence and risk factors of esophageal candidiasis in healthy individuals: a single center experience in Korea. Yonsei Med J 2013;54:160-5.

10. Takahashi Y, Nagata N, Shimbo T, et al. Long-term trends in esophageal candidiasis prevalence and associated risk factors with or without HIV infection: lessons from an endoscopic study of 80,219 patients. PLoS One 2015; 10:e0133589

11. Alsomali MI, Arnold MA, Frankel WL, et al. Challenges to "Classic" esophageal candidiasis: Looks are usually deceiving. Am J Clin Pathol 2017;147:33-42

12. Walsh TJ, Hamilton SR, Belitsos N. Esophageal candidiasis. Managing an increasingly prevalent infection. Postgrad Med 1988;84:193-6, 201-

13. Arendrup MC. Epidemiology of invasive candidiasis. Curr Opin Crit Care 2010;16:445-52.

14. Jarvis WR. Epidemiology of nosocomial fungal infections, with emphasis on Candida species. Clin Infect Dis 1995;20:1526-30.

15. Hoversten P, Otaki F, Katzka DA. Course of esophageal Candidiasis and outcomes of patients at a single center. Clin Gastroenterol Hepatol 2019; 17:200-2.

16. Takahashi Y, Nagata N, Shimbo T, et al. Upper gastrointestinal symptoms predictive of Candida esophagitis and erosive esophagitis in HIV and non-HIV patients. Medicine (Baltimore) 2015;94:e2138. 